\title{
Bark Beetles, Pityogenes bidentatus, Orienting to Aggregation Pheromone Avoid Conifer Monoterpene Odors When Flying but Not When Walking
}

\author{
John A. Byers \\ US Arid-Land Agricultural Research Center, ARS, USDA, 21881 North Cardon Lane, Maricopa, AZ 85138, USA \\ Correspondence should be addressed to John A. Byers, john.byers@ars.usda.gov
}

Received 17 December 2011; Revised 14 March 2012; Accepted 25 April 2012

Academic Editor: Brian T. Sullivan

Copyright (C) 2012 John A. Byers. This is an open access article distributed under the Creative Commons Attribution License, which permits unrestricted use, distribution, and reproduction in any medium, provided the original work is properly cited.

\begin{abstract}
Previous studies and data presented here suggest that odors from healthy host Scotch pine (Pinus sylvestris) and nonhost Norway spruce (Picea abies), as well as major monoterpenes of these trees at natural release rates, significantly reduce the attraction of flying bark beetles, Pityogenes bidentatus, of both sexes to their aggregation pheromone components grandisol and cis-verbenol in the field, as tested by slow rotation of trap pairs. In contrast, P. bidentatus males and females walking in an open-arena olfactometer in the laboratory did not avoid monoterpene vapors at release rates spanning several orders of magnitude in combination with aggregation pheromone. The bark beetle may avoid monoterpenes when flying as a mechanism for avoiding nonhost species, vigorous and thus unsuitable host trees, as well as harmful resinous areas of hosts. Inhibition of this flight avoidance response in beetles after landing would allow them to initiate, or to find and enter, gallery holes with high monoterpene vapor concentrations in order to feed and reproduce.
\end{abstract}

\section{Introduction}

The bark beetle Pityogenes bidentatus (Herbst) (Coleoptera: Curculionidae: Scolytinae) is a relatively small (2-3 mm long) insect that attacks only Scotch pine, Pinus sylvestris L. [1]. The beetle is common in Scotch pine and mixed conifer forests of Europe where it begins a seasonal flight in spring and colonizes smaller diameter trunks and limbs of weakened hosts [1-3]. The species builds up in slash and logging residue and can harm adjacent young stands of Scotch pine [3]. P. bidentatus have been caught more frequently in traps baited with pine logs left for several weeks compared to freshly-cut logs, indicating that the beetle is attracted to odors from aging tissue [4]. The aggregation pheromone of $P$. bidentatus consists of two components, $(S)$-cis-verbenol (cV) and grandisol (G1) as determined in previous studies [5-9]. Grandisol is well known as a pheromone component of the boll weevil, Anthonomus grandis Boheman [10].

Injured conifers such as pines and spruce produce resin, commonly consisting of about $80 \%$ mildly toxic monoterpenes, to defend against the penetrations of attacking insects
[11]. Some species of bark beetles may be attracted to these tree-specific blends of monoterpenes [12, 13] since they indicate both the appropriate host and the likely susceptibility to colonization [14-17]. Bark beetles in the genus Tomicus exhibit relatively strong attraction to host Scotch pine and its major monoterpenes, especially $\alpha$ pinene (both enantiomers), $(+)-3$-carene, and terpinolene [14-17]. Camphene, (+)- and (-)- $\alpha$-pinene, and (-)- $\beta-$ pinene are major monoterpenes of Norway spruce, Picea abies L., the host of $P$. chalcographus L. These monoterpenes enhance the attraction of flying $P$. chalcographus to traps baited with its aggregation pheromone, and increase entry rates of the beetles through $2.5 \mathrm{~mm}$ diameter holes into the traps $[18,19]$. Furthermore, several studies have found that certain monoterpenes enhance attraction to pheromone components in some of the more aggressive bark beetles that kill standing trees [18-25].

On the other hand, a sufficient flow of resin can expel or kill attacking bark beetles. Hence less aggressive species of bark beetles that specialize on hosts with compromised resin defenses may have evolved olfactory mechanisms and 
behaviors for the avoidance of specific volatile monoterpenes in tree resins indicative of a vigorous and resistant tree. Likewise beetles apparently avoid certain monoterpenes or other volatile chemicals associated specifically with nonhost tree species [26-37]. This appears to be the case for flying $P$. bidentatus when orienting to their aggregation pheromone components. Odors from freshly-cut host Scotch pine or from non-host Norway spruce, as well as nonhost deciduous trees (birch, Betula pendula Roth.; mountain ash, Sorbus aucuparia L.; oak, Quercus robur L. and alder buckthorn, Frangula alnus P. Mill.) reduced attraction to the aggregation pheromone components $[7,8]$. Many individual monoterpenes and blends released at rates comparable to that released from physical wounds of trees also inhibited flight attraction to their aggregation pheromone [7-9].

Three previous studies [7-9] tested effects of monoterpenes on flying $P$. bidentatus by using a pair of traps separated $6 \mathrm{~m}$ apart that were mechanically rotated slowly at $2 \mathrm{rph}$ to even out any trap position effects $[7,8,38]$. Both traps contained aggregation pheromone ( $\mathrm{G} 1$ and $\mathrm{cV}$ ), while one trap also released host or nonhost odors (specific monoterpenes, cut bark, or twigs) that reduced attraction of flying P. bidentatus (Figure 1). The objective of my study was to assess the response of both flying and walking $P$. bidentatus of both sexes to monoterpenes released in association with the aggregation pheromone (assayed with either rotating traps in the field or a laboratory olfactometer, resp.). The hypothesis was that aggregation pheromone responses by beetles walking in the olfactometer would exhibit the same inhibition to monoterpenes as when flying in the field. This hypothesis was based on earlier studies with bark beetle semiochemicals in which the same behavioral responses (attraction or repulsion) were found both when beetles were walking in a laboratory olfactometer and when flying in the field to baited traps $[7,8,14,15,18,19,39-42]$.

\section{Materials and Methods}

2.1. Inhibition of Attractive Response of Flying P. bidentatus to Aggregation Pheromone Components by Monoterpenes. Field tests similar to those mentioned above [7-9] were conducted in mixed forests/plantations (primarily Scotch pine) near Sjöbo/Veberöd, Sweden in May 2001 with three sets of rotating trap pairs. Traps in each pair were $6 \mathrm{~m}$ apart, suspended at $1.2 \mathrm{~m}$ height, and rotated around a central axis at $2 \mathrm{rph}$. Synthetic aggregation components G1 (racemic, cis-grandisol, (1R, 2S)-1-(2-hydroxyethyl)-1-methyl-2-(1methylethenyl) cyclobutane, $>98 \%$, Frank Enterprises, Inc., Columbus, Ohio) and cV $((1 S, 4 S, 5 S)$-cis-verbenol, 96\%, Borregaard) were placed inside each trap in a pair. Each pheromone bait had $25 \mu \mathrm{L} \mathrm{G1}$ at the bottom of a small glass tube $(34 \mathrm{~mm} \times 4.45 \mathrm{~mm}$ i.d. opening $)$ and $\sim 25 \mathrm{mg}$ of crystalline $\mathrm{cV}$ at the bottom of a polyethylene tube $(31 \mathrm{~mm}$ $\times 6.15 \mathrm{~mm}$ i.d. opening) so that releases were nearly constant (0.05 $\mathrm{mg} \mathrm{G} 1 /$ day and $0.5 \mathrm{mg} \mathrm{cV} /$ day at $\left.22^{\circ} \mathrm{C}\right)$.

Each trap consisted of an $18 \mathrm{~cm}$ diameter $\times 28 \mathrm{~cm}$ high transparent polycarbonate cylinder covered at the top but open at the bottom and suspended over a large white plastic funnel $(31 \mathrm{~cm}$ diameter) that collected beetles striking the

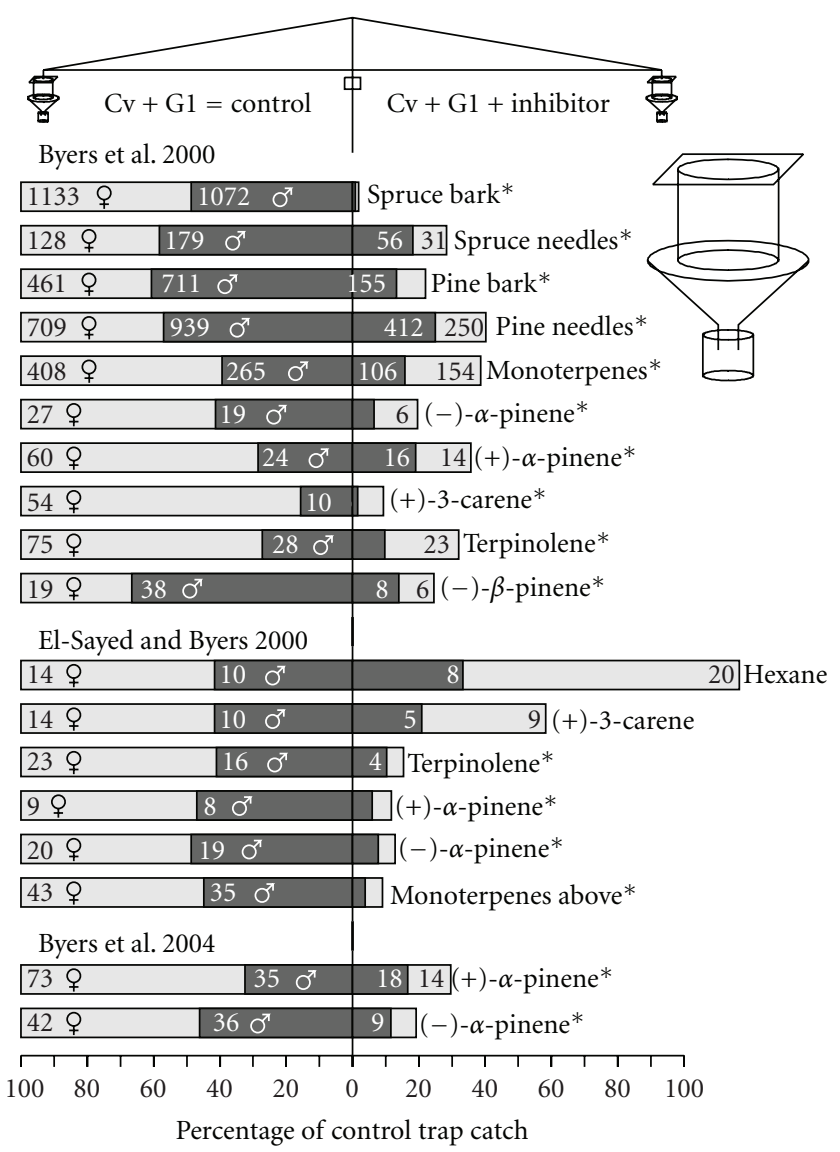

Figure 1: Selected comparisons from three studies (Byers et al. [7], El-Sayed and Byers [9], and Byers et al. [8]) showing reduced catches of flying Pityogenes bidentatus on traps releasing pheromone plus inhibitor volatiles (monoterpenes released at $1 \mathrm{mg} /$ day, 100 $200 \mathrm{~g}$ bark or needles of spruce and pine) compared to control traps with pheromone alone (Sjöbo/Veberöd, Sweden, April-May 19982000, see Methods for details). Total catches of both sexes with asterisks were significantly lower than the pheromone controls in the same test at $P<0.01$ (chi-square goodness of fit).

cylinder (Figure 1). Experimental runs of each rotating trap pair were conducted for at least 1 hour during 11:0018: 00 when temperature was above $18^{\circ} \mathrm{C}$. After each run the inhibitory source, but not the attractants, was switched to the other trap of the pair such that from two to five runs were conducted for each monoterpene test. The monoterpenes tested as inhibitors included $(+)-\alpha$-pinene $\left([\alpha]_{D}^{20}=+57^{\circ}\right.$, $99 \%$, Fluka, Stockholm, Sweden), (-)- $\alpha$-pinene $\left([\alpha]_{D}^{20}=\right.$ $-50^{\circ},>99.5 \%$, Fluka), (+)-3-carene $\left([\alpha]_{D}^{20}=+15^{\circ}, 95 \%\right.$, Aldrich, Stockholm, Sweden), terpinolene (97\% Carl Roth Gmbh, Karlsruhe, Germany), and $(-)-\beta$-pinene $\left([\alpha]_{D}^{20}=\right.$ $-21^{\circ}, 99 \%$, Aldrich), myrcene (95\%, Aldrich), (-)-limonene $\left([\alpha]_{D}^{20}=-94^{\circ}, 96 \%\right.$, Aldrich $)$, and $(+)$-limonene $\left([\alpha]_{D}^{20}=\right.$ $+123^{\circ}, 97 \%$, Aldrich). The release rates $(\mu \mathrm{g} / \mathrm{h})$ were about 1400 for $\alpha$-pinene enantiomers, 800 for $(-)$ - $\beta$-pinene, 740 for myrcene, 385 for each enantiomer of limonene, and 240 for terpinolene released individually from glass tubes as described above (weight loss at $22^{\circ} \mathrm{C}$ in laboratory). 
The catches on inhibitor and control were pooled for each treatment comparison and tested for significant differences by comparing the two catches to the average catch with a chisquare test $(d f=1)$. If the tests were statistically significant $(P<0.05)$, then catches of each sex were compared within a treatment comparison for significant differences using a chi-square test. Previous results (Figure 1) [7, 8] were also analyzed for gender differences in regard to inhibition of attraction.

Previously reported dose-response data for monoterpene reduction of $P$. bidentatus attraction to G1 and $\mathrm{cV}$ (Figure 4 in [9]) was subjected to user-defined logarithmic and logistic dose-response regressions (Statistica 5.1, StatsSoft Inc., Tulsa $\mathrm{OK}$ ) to find a better relationship than originally presented. In this previously reported test, responses of both sexes to the pheromone-baited, slow-rotating trap pairs were compared after one trap of the pair was amended with an exact release of four host monoterpenes ranging from 0.01 to 10 Scotch pine log equivalents ( 0.1 to $100 \mu \mathrm{g} / \mathrm{min}$ each monoterpene) provided by a piezoelectric sprayer and syringe pump [9].

2.2. Tests for Inhibition of the Attractive Response of Walking P. bidentatus to Aggregation Pheromone Components in a Laboratory Open-Arena Olfactometer. Adults of P. bidentatus that had been caught live in traps baited with aggregation pheromone components, G1 and $\mathrm{cV}$ at the same field sites described above during May 1999 and 2000 were separated by sex in the laboratory. They were then stored at $4^{\circ} \mathrm{C}$ on moistened tissue paper in Petri dishes for up to four days until use in bioassays. The responses of $P$. bidentatus to semiochemicals were tested in a modified open-arena olfactometer [14, 15, 19, 41, 43]. This consisted of a suction fan that drew air out of the room through a fine metal screen $(0.4 \mathrm{~mm}$ mesh $)$ on one side of an opaque plastic manifold $(60 \mathrm{~cm}$ wide $\times 25 \mathrm{~cm} \times 25 \mathrm{~cm})$ placed on the "downwind" side of a glass tabletop covered with white construction/poster paper $(0.84 \times 1.1 \mathrm{~m})$. At the "upwind" end of the table $(0.7 \mathrm{~m}$ from the manifold), laboratory air was forced through a clear acrylic manifold $(46 \mathrm{~cm}$ wide $\times 5 \mathrm{~cm}$ high $\times 8.5 \mathrm{~cm}$ deep) with three rows of 13 , 12 , and 13 holes ( $1.5 \mathrm{~mm}$ diameter) starting $7.5 \mathrm{~mm}$ above the surface (with spacing between holes $3 \mathrm{~cm}$ horizontally and $1 \mathrm{~cm}$ vertically; middle row of 12 holes centered). The two manifolds maintained an approximately laminar airflow with a speed of $0.9 \mathrm{~m} / \mathrm{s}$ at the semiochemical source $(5 \mathrm{~cm}$ from the center of upwind manifold) and $0.6 \mathrm{~m} / \mathrm{s}$ where the beetles were released $(21 \pm 2 \mathrm{~cm}$ "downwind" from the source). Ten beetles of a single sex were released together initially. A positive response was recorded when a beetle arrived within $2 \mathrm{~cm}$ of the odor source. Beetles that walked outside a $25 \mathrm{~cm}$ radius circle centered on the release point, or that had not reached the odor source in the time required for various mixtures of the semiochemicals in diethyl ether to finish eluting $(126 \pm 10 \mathrm{sec})$ from a $5 \mu \mathrm{L}$ glass capillary (Drummond Scientific, Broomall, PA), were placed temporarily in a plastic Petri dish until the first trial was completed. These nonresponding beetles were released a second time to a newly filled capillary tube and the numbers reaching the odor source in the two trials were summed (e.g., two of ten may have responded in the first trial and two of eight in the second trial giving a $40 \%$ response in total).

The aggregation pheromone components $\mathrm{cV}$ and G1 were released together in the laboratory in two ways: (1) diluted in diethyl ether and placed in a $5-\mu \mathrm{L}$ capillary tube open at both ends, or (2) in the field dispensers described above. The release rates for the second method were estimated by weight loss at $22^{\circ} \mathrm{C}$ to be $350 \mathrm{ng} / \mathrm{min}$ for $\mathrm{cV}$ and $35 \mathrm{ng} / \mathrm{min}$ for $\mathrm{Gl}$, the same rates released in the slow-rotating pairs of traps in field tests. The release of monoterpenes was by the first method only, although the compounds were also dispensed neat from the $5-\mu \mathrm{L}$ capillary. In method 1 , release rates of chemicals from the $5-\mu \mathrm{L}$ capillary were dependent on the evaporation of the solvent diethyl ether; that is, $2.2 \mu \mathrm{L}$ of ether was released per min and thus the release rates were about 2.2 times the concentration (in mass per $\mu \mathrm{L}$ ) for each dilution tested as indicated in Tables 1,2 , and 3 .

The monoterpenes tested were (+)- $\alpha$-pinene, $(-)-\alpha$ pinene, (+)-3-carene, terpinolene, and $(-)-\beta$-pinene as described above. The two aggregation pheromone components $(\mathrm{G} 1$ and $\mathrm{cV})$ were tested together without monoterpenes or together with monoterpenes and compared in some cases to a diethyl ether control in three sets of bioassays (4 May 1999, 7 June 1999, and 21-23 May 2000). At least 40 beetles of each sex were tested for each release rate of the compounds under conditions of $22^{\circ} \mathrm{C}$ and 1700 lux during 13:00-17:00. Both sexes were tested at the lowest chemical concentrations initially each day and then additional beetles were tested at increasingly higher concentrations as indicated in the tables. The release rates were chosen based on behavioral results with other bark beetles in previous studies with the same olfactometer [14$16,19]$ as well as to correspond to rates used in the field (which represent natural release rates from Scotch pine logs or bark beetles) $[9,14-18]$. The release of neat monoterpenes in the open-arena bioassay were determined precisely in 2012 under the same olfactometer conditions by measuring changes in meniscus volume of the capillary as monitored by a time-lapse webcam and computer (Byers unpublished). Statistically significant differences in the percent responding between various release rates and compound combinations were determined by a chi-square test.

\section{Results}

3.1. Inhibition of Attractive Response of Flying P. bidentatus to Aggregation Pheromone Components by Monoterpenes. In tests of rotating pairs of aggregation pheromone-baited traps, the single trap of each pair dispensing vapor of individual monoterpenes generally caught fewer $P$. bidentatus than its paired control trap (Figure 2). Myrcene was not tested in the earlier studies (Figure 1) and was inhibitory to P. bidentatus response (Figure 2). Also, the enantiomers of limonene had not been tested earlier and, contrary to other monoterpenes, these did not appear to reduce response of either sex of the bark beetle (Figure 2). In tests that showed a significant reduction in total catch by monoterpenes (Figure 2), attraction of each sex was inhibited in flight in 
Table 1: Percent of walking Pityogenes bidentatus females and males responding in a laboratory olfactometer (4 May 1999) to conifer monoterpenes and aggregation pheromone components $(\mathrm{Gl}=$ grandisol, $\mathrm{cV}=(S)$-cis-verbenol).

\begin{tabular}{|c|c|c|c|}
\hline Chemicals $^{\mathrm{a}}$ & Percent responding ${ }^{\mathrm{b}}$ & 95\% B. C. L. ${ }^{c}$ & $N$ \\
\hline \multicolumn{4}{|l|}{ Females } \\
\hline Diethyl ether control & $10.0 \mathrm{a}$ & $4.0-23.1$ & 40 \\
\hline $\mathrm{A}=\mathrm{G} 1+\mathrm{cV}$ at $5 \times 10^{-10} \mathrm{~g} / \mu \mathrm{L}$ & $42.5 b$ & $28.5-57.8$ & 40 \\
\hline $\mathrm{A}+$ monoterpenes $^{\mathrm{d}}$ at $5 \times 10^{-9} \mathrm{~g} / \mu \mathrm{L}$ & $37.5 b$ & $24.5-53.0$ & 40 \\
\hline $\mathrm{A}+$ monoterpenes $^{\mathrm{d}}$ at $5 \times 10^{-8} \mathrm{~g} / \mu \mathrm{L}$ & $30 \mathrm{~b}$ & $18.1-45.4$ & 40 \\
\hline $\mathrm{A}+$ monoterpenes $^{\mathrm{d}}$ at $5 \times 10^{-7} \mathrm{~g} / \mu \mathrm{L}$ & $32.5 b$ & $20.1-48.0$ & 40 \\
\hline $\mathrm{A}+$ monoterpenes $^{\mathrm{d}}$ at $5 \times 10^{-6} \mathrm{~g} / \mu \mathrm{L}$ & $37.5 b$ & $24.2-53.0$ & 40 \\
\hline \multicolumn{4}{|l|}{ Females } \\
\hline $\mathrm{B}=\mathrm{G} 1+\mathrm{cV}$ at $5 \times 10^{-9} \mathrm{~g} / \mu \mathrm{L}$ & $72.5 \mathrm{a}$ & $49.5-77.9$ & 40 \\
\hline $\mathrm{B}+$ monoterpenes $^{\mathrm{d}}$ at $5 \times 10^{-7} \mathrm{~g} / \mu \mathrm{L}$ & $52.5 \mathrm{a}$ & $37.5-67.1$ & 40 \\
\hline $\mathrm{B}+$ monoterpenes $^{\mathrm{d}}$ at $5 \times 10^{-6} \mathrm{~g} / \mu \mathrm{L}$ & $57.5 \mathrm{a}$ & $42.2-71.5$ & 40 \\
\hline \multicolumn{4}{|l|}{ Females } \\
\hline $\mathrm{C}=\mathrm{G} 1+\mathrm{cV}$ field dispensers & $45 \mathrm{a}$ & $34.6-55.9$ & 80 \\
\hline $\mathrm{C}+$ monoterpenes $^{\mathrm{d}}$ at $5 \times 10^{-5} \mathrm{~g} / \mu \mathrm{L}$ & $48.75 \mathrm{a}$ & $38.1-59.5$ & 80 \\
\hline \multicolumn{4}{|l|}{ Males } \\
\hline $\mathrm{C}$ & $33.33 \mathrm{a}$ & $22.7-45.9$ & 60 \\
\hline $\mathrm{C}+$ monoterpenes $^{\mathrm{d}}$ at $5 \times 10^{-5} \mathrm{~g} / \mu \mathrm{L}$ & $38.33 \mathrm{a}$ & $27.1-51.0$ & 60 \\
\hline
\end{tabular}

${ }^{a}$ Chemicals dispensed by evaporation from $5 \mu \mathrm{L}$ micropipette at indicated concentration each $/ \mu \mathrm{L}$ diethyl ether (release rate approximately $2.2 \times$ concentration/ $\min )$.

${ }^{b}$ Percentages followed by same letter were not significantly different ( $\alpha=0.05$, chi-square) within a test series for each sex.

${ }^{\mathrm{c}}$ Binomial confidence limits for proportions.

${ }^{\mathrm{d}}$ Major host Scotch pine monoterpenes: $(+)-\alpha$-pinene, $(-)-\alpha$-pinene, $(+)-3$-carene, and terpinolene were dispensed in diethyl ether solution at concentrations indicated in table.

TABle 2: Percent of walking Pityogenes bidentatus females and males responding in a laboratory olfactometer (7 June 1999) to conifer monoterpenes and aggregation pheromone components $(\mathrm{Gl}=$ grandisol, $\mathrm{cV}=(S)$-cis-verbenol).

\begin{tabular}{|c|c|c|c|}
\hline Chemicals $^{\mathrm{a}}$ & Percent responding ${ }^{\mathrm{b}}$ & $95 \%$ B. C. L. ${ }^{c}$ & $N$ \\
\hline \multicolumn{4}{|l|}{ Females } \\
\hline $\mathrm{B}=\mathrm{G} 1+\mathrm{cV}$ at $10^{-9} \mathrm{~g} / \mu \mathrm{L}$ & $68.3 \mathrm{a}$ & $55.8-78.7$ & 60 \\
\hline $\mathrm{B}+$ monoterpenes $^{\mathrm{d}}$ at $10^{-5} \mathrm{~g} / \mu \mathrm{L}$ & $65.0 \mathrm{a}$ & $52.4-75.8$ & 60 \\
\hline $\mathrm{B}+$ monoterpenes neat $^{\mathrm{e}}$ & $70.0 \mathrm{a}$ & $57.5-80.1$ & 60 \\
\hline $\mathrm{B}+(-)-\alpha$-pinene neat ${ }^{\mathrm{e}}$ & $75.0 \mathrm{a}$ & $62.8-84.2$ & 60 \\
\hline \multicolumn{4}{|l|}{ Males } \\
\hline B & $65.0 \mathrm{a}$ & $52.4-75.8$ & 60 \\
\hline $\mathrm{B}+(-)-\alpha$-pinene neat ${ }^{\mathrm{e}}$ & $71.7 \mathrm{a}$ & $59.2-81.5$ & 60 \\
\hline
\end{tabular}

${ }^{\mathrm{a}}$ Chemicals dispensed by evaporation from $5 \mu \mathrm{L}$ micropipette at indicated concentration each/ $\mu \mathrm{L}$ diethyl ether (release rate approximately $2.2 \times$ concentration/ min except when neat).

${ }^{\mathrm{b}}$ Percentages followed by same letter were not significantly different $(\alpha=0.05$, chi-square).

${ }^{\mathrm{c}}$ Binomial confidence limits for proportions.

dMajor host Scotch pine monoterpenes: $(+)-\alpha$-pinene, $(-)-\alpha$-pinene, $(+)$-3-carene, and terpinolene were each at indicated concentration as dispensed in diethyl ether solution.

${ }^{\mathrm{e}}$ Chemicals were dispensed neat from $5 \mu \mathrm{L}$ micropipettes; (-)- $\alpha$-pinene, (+)-3-carene, and terpinolene were each released at 28, 9.4, and 4.8 $\mu \mathrm{g} / \mathrm{min}$, respectively, according to capillary measurements over time in the olfactometer.

nearly all cases $(P<0.01)$, except male response to $(-)-\alpha-$ pinene $(P=0.02)$ and to $(+)$ - $\alpha$-pinene $(P=0.012)$ were only marginally significant due likely to low numbers. The inhibition of the beetle by $(+)-3$-carene $(P<0.01)$ was mainly due to females $(P<0.01)$ because male catches were not significantly different $(P=0.56)$, but again the numbers of males caught were low (Figure 2). However, males and females were inhibited in an earlier study [7] by (+)-3carene (Figure 1, both sexes $P<0.01$ ). In the reanalysis of previous studies catches of each gender (Figure 1), both sexes were significantly inhibited in flight by non-host Norway spruce and host Scotch pine odors as well as by several monoterpenes: $\alpha$-pinene, $\beta$-pinene, 3 -carene, and terpinolene tested singly or as a combination (all $P<0.01$ ). 
Table 3: Percent of walking Pityogenes bidentatus females and males responding in a laboratory olfactometer (21-23 May 2000) to conifer monoterpenes and its aggregation pheromone components ( $\mathrm{Gl}=$ grandisol, cV = S-cis-verbenol).

\begin{tabular}{|c|c|c|c|}
\hline Chemicals $^{\mathrm{a}}$ & Percent responding ${ }^{\mathrm{b}}$ & 95\% B. C. L. ${ }^{c}$ & $N$ \\
\hline \multicolumn{4}{|l|}{ Females } \\
\hline Diethyl ether control & $10.0 \mathrm{a}$ & $4.0-23.1$ & 40 \\
\hline $\mathrm{A}=\mathrm{G} 1+\mathrm{cV}$ at $5 \times 10^{-10} \mathrm{~g} / \mu \mathrm{L}$ & $25.0 \mathrm{ab}$ & $14.2-40.2$ & 40 \\
\hline $\mathrm{B}=\mathrm{G} 1+\mathrm{cV}$ at $5 \times 10^{-9} \mathrm{~g} / \mu \mathrm{L}$ & $35.0 \mathrm{~b}$ & $22.1-50.5$ & 40 \\
\hline $\mathrm{G} 1+\mathrm{cV}$ at $5 \times 10^{-8} \mathrm{~g} / \mu \mathrm{L}$ & $42.5 b c$ & $28.5-57.8$ & 40 \\
\hline $\mathrm{D}=\mathrm{G} 1+\mathrm{cV}$ at $5 \times 10^{-7} \mathrm{~g} / \mu \mathrm{L}$ & $62.5 \mathrm{~cd}$ & $47.0-75.8$ & 40 \\
\hline $\mathrm{D}+(-)-\beta$-pinene at $10^{-5} \mathrm{~g} / \mu \mathrm{L}$ & $72.5 \mathrm{~d}$ & $57.2-83.9$ & 40 \\
\hline $\mathrm{D}+(-)-\alpha$-pinene at $10^{-5} \mathrm{~g} / \mu \mathrm{L}$ & $65.0 \mathrm{~cd}$ & $49.5-77.9$ & 40 \\
\hline \multicolumn{4}{|l|}{ Males } \\
\hline Diethyl ether control & $5.0 \mathrm{a}$ & $1.4-16.5$ & 40 \\
\hline $\mathrm{A}=\mathrm{G} 1+\mathrm{cV}$ at $5 \times 10^{-10} \mathrm{~g} / \mu \mathrm{L}$ & $17.5 \mathrm{a}$ & $8.7-32.0$ & 40 \\
\hline $\mathrm{B}=\mathrm{G} 1+\mathrm{cV}$ at $5 \times 10^{-9} \mathrm{~g} / \mu \mathrm{L}$ & $42.5 b$ & $28.5-57.8$ & 40 \\
\hline $\mathrm{G} 1+\mathrm{cV}$ at $5 \times 10^{-8} \mathrm{~g} / \mu \mathrm{L}$ & $40.0 \mathrm{~b}$ & $26.3-55.4$ & 40 \\
\hline $\mathrm{D}=\mathrm{G} 1+\mathrm{cV}$ at $5 \times 10^{-7} \mathrm{~g} / \mu \mathrm{L}$ & $50.0 \mathrm{~b}$ & $35.2-64.8$ & 40 \\
\hline $\mathrm{D}+(-)-\beta$-pinene at $10^{-5} \mathrm{~g} / \mu \mathrm{L}$ & $47.5 b$ & $32.9-62.5$ & 40 \\
\hline $\mathrm{D}+(-)-\alpha$-pinene at $10^{-5} \mathrm{~g} / \mu \mathrm{L}$ & $55.0 \mathrm{~b}$ & $39.8-69.3$ & 40 \\
\hline
\end{tabular}

${ }^{\mathrm{a}}$ Chemicals dispensed by evaporation from $5 \mu \mathrm{L}$ micropipette at indicated concentration each $/ \mu \mathrm{L}$ diethyl ether (release rate approximately $2.2 \times$ concentration/ $\min )$.

${ }^{b}$ Percentages followed by same letter were not significantly different ( $\alpha=0.05$, chi-square).

${ }^{\mathrm{c}}$ Binomial confidence limits for proportions.

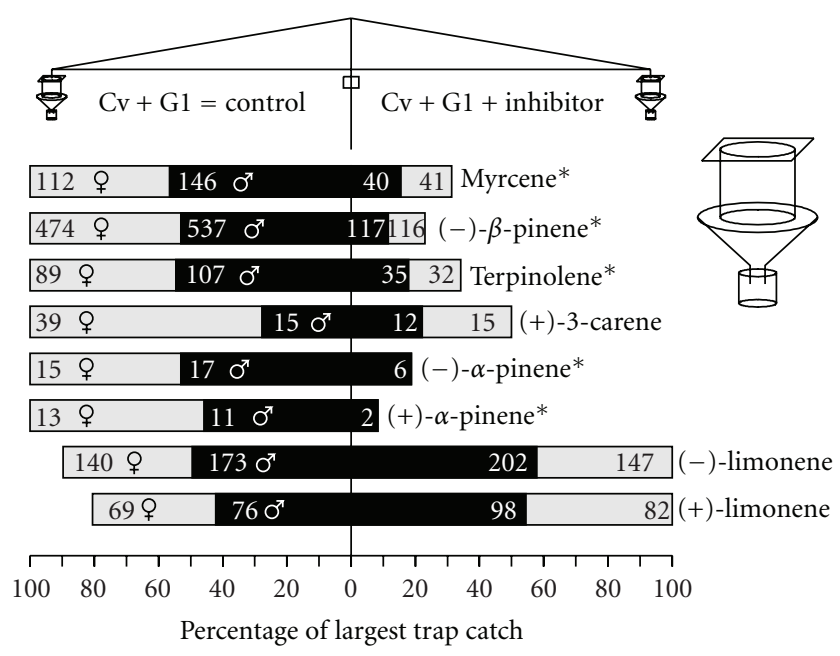

Figure 2: Attraction of flying Pityogenes bidentatus to pairs of slowly-rotated traps releasing aggregation pheromone (cisverbenol $=\mathrm{Cv}$ and grandisol $=\mathrm{G} 1$ ) when individual monoterpenes were released from one of the two traps. Tests were performed at different dates and times during May 2001 in Sjöbo/Veberöd, Sweden. Numbers inside light and black bars represent catch of each sex. Treatments with asterisks caught significantly fewer beetles (sexes summed) in the treatment than the control trap in the same pair $(P<0.01$, chi-square test $)$.

In one study [7], however, males were not inhibited by $(+)-\alpha-$ pinene $(P=0.20)$ possibly due to low numbers trapped ( 10 and 5 males). In a second study [8], both sexes were inhibited by either enantiomer of $\alpha$-pinene (all $P<0.01$ ). In a third study [9], (+)-3-carene was not significantly inhibitory for either sex (both $P>0.2$ ), although low numbers were caught as in the second study (Figure 1).

Reanalysis of a similar published study [9], in which one trap of each pair had exact releases of four host monoterpenes representing 0.01 to 10 pine log equivalents, revealed that the dose-response data best fit a logistic regression $\left(R^{2}=0.86\right.$; equation in Figure 3$)$. The common logarithmic regression, $Y=24.824-5.087 \cdot \ln (X)$, also fits well $\left(R^{2}=\right.$ $0.84)$.

3.2. Tests for Inhibition of the Attractive Response of Walking P. bidentatus to Aggregation Pheromone Components in a Laboratory Open-Arena Olfactometer. The responses of walking female $P$. bidentatus to aggregation pheromone components grandisol (G1) and cis-verbenol $(\mathrm{cV})$ at $5 \times 10^{-10} \mathrm{~g} / \mu \mathrm{L}$ concentration was $42.5 \%$ (Table 1). An increasing dosage of four host Scotch pine monoterpenes (each compound ranged from 10 to 10,000 times the concentration of the pheromone components) did not significantly affect the attraction of walking females to this concentration of G1 and $\mathrm{cV}$ (Table 1), as would be expected from the field trapping experiments above. In another bioassay series, a stronger aggregation dose of $5 \times 10^{-9} \mathrm{~g} / \mu \mathrm{L}$ caused $72.5 \%$ of females to respond, and the addition to this dosage of the four monoterpenes at 1000 to 10,000 times higher concentrations caused a slightly lower response, but this difference was not significant (Table 1). The addition of monoterpenes at the strongest dosage of $10^{-5} \mathrm{~g} / \mu \mathrm{L}$ had no effect on attraction in either sex to the field dispensers of G1 and cV (Table 1).

In a second series of bioassays, a dosage of $10^{-9} \mathrm{~g} / \mu \mathrm{L}$ $\mathrm{G} 1+\mathrm{cV}$ that alone attracted $68.3 \%$ females was combined 


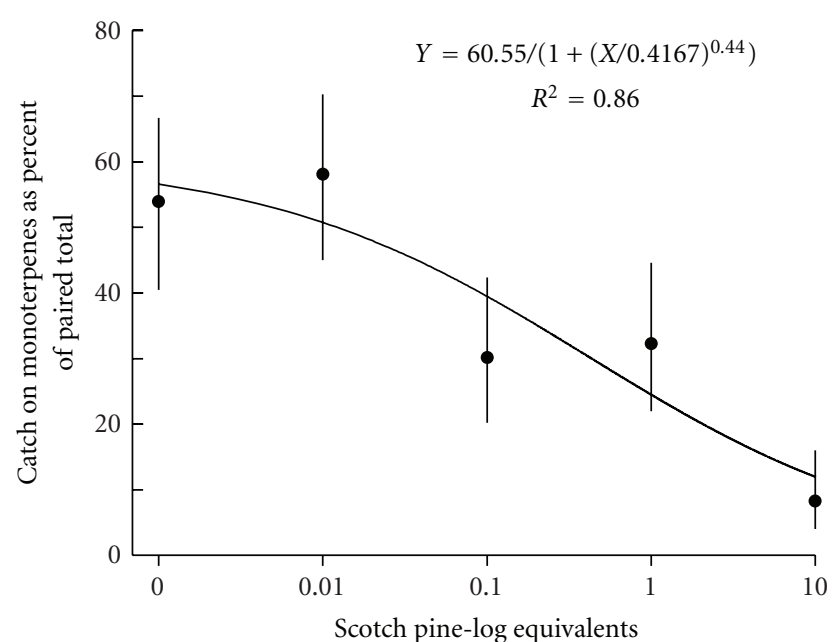

Figure 3: Inhibition of $P$. bidentatus response by increasing release rates of a mixture of Scotch pine monoterpenes $((-)$ - $\alpha$-pinene, $(+)$ - $\alpha$-pinene, (+)-3-carene, and terpinolene) each released in proportion to release of 1.0 Scotch pine log-equivalent $(10 \mu \mathrm{g} / \mathrm{min})$ in hexane with the piezoelectric sprayer from one of a pair of slowly-rotated, pheromone (cis-verbenol and grandisol)-baited traps (Veberöd, Sweden, 19 May 1999; data from [9]). Error bars represent $95 \%$ binomial confidence limits for the proportion trapped in the monoterpene-releasing trap relative to the total catches by the pair.

with the strongest dosage tested of monoterpenes $\left(10^{-5} \mathrm{~g} / \mu \mathrm{L}\right.$ or neat monoterpenes), but their response was not reduced (Table 2). Walking males responded similarly as females to the aggregation pheromone components and there was no evidence of any inhibition by host tree monoterpenes released neat from the $5-\mu \mathrm{L}$ pipette (Table 2). The releases of neat monoterpenes in the open-arena olfactometer for $\alpha$-pinene, 3-carene, and terpinolene were 28, 9.4, and $4.8 \mu \mathrm{g} / \mathrm{min}$, respectively.

A third series of bioassays a year later was performed in which the release rate of the aggregation pheromone components was increased over several orders of magnitude from $5 \times 10^{-10}$ to $5 \times 10^{-7} \mathrm{~g} / \mu \mathrm{L}$, which resulted in an increasing response of walking females and males to the source (Table 3). But again, a strong release of $10^{-5} \mathrm{~g} / \mu \mathrm{L}$ of monoterpenes, either $(-)-\beta$-pinene (a major monoterpene of non-host Norway spruce but not of host pine) or (-)- $\alpha$ pinene (a major monoterpene in both Scotch pine and Norway spruce), did not decrease response to an optimal dosage $\left(5 \times 10^{-7} \mathrm{~g} / \mu \mathrm{L}\right)$ of the aggregation pheromone components (Table 3).

\section{Discussion}

The results of selected tests from the three previous studies [7-9] showed strong to moderate inhibition of the flight orientation of both sexes of $P$. bidentatus to synthetic aggregation pheromone components in the field (Figure 1). Norway spruce bark was highly inhibitory as well as spruce needles, but even the host tree Scotch pine bark or needles were strongly inhibitory (Figure 1). Mixtures of monoterpenes as well as five individual host monoterpenes clearly cause flying $P$. bidentatus of both sexes to avoid landing on traps releasing aggregation pheromone when compared to traps releasing the same rate of pheromone without inhibitory volatiles (Figures 1 and 2). The current field tests (Figure 2), show that P. bidentatus of both sexes avoid landing in areas with aggregation pheromone if the monoterpenes myrcene, $(-)-\beta$-pinene, terpinolene, $(-)-\alpha$-pinene, and $(+)-$ $\alpha$-pinene are also released. Only females were significantly inhibited by $(+)-3$-carene, while neither sex appeared to avoid either enantiomer of limonene when orienting to aggregation pheromone (Figure 2).

In the laboratory bioassay with walking beetles, however, several monoterpenes released with aggregation pheromone components had no apparent effect on attraction (Tables 13 ). The large range of monoterpene release rates over three orders of magnitude in the laboratory bioassay are estimated to correspond to natural release rates from small wounds to broken limbs of conifers $[14,15]$, and were similar to the rates that elicited behavioral activity (attraction) from Tomicus piniperda (L.) and T. minor (Hart.) in the same laboratory olfactometer [14-16]. The highest concentration of ether-diluted monoterpenes tested in the laboratory olfactometer $\left(10^{-5} \mathrm{~g} / \mu \mathrm{L}\right)$ had a maximum estimated release rate of $1300 \mu \mathrm{g} / \mathrm{h}$, which is comparable to the release rate in field trials (i.e., 1000 to $1400 \mu \mathrm{g} / \mathrm{h}$ ) that caused inhibition of attraction [7]. The actual release rates of monoterpenes dissolved in diethyl ether from the 5- $\mu \mathrm{L}$ capillary, however, were probably different due to differing vapor pressures of the monoterpenes and diethyl ether [41]. However, the highest release rates of neat monoterpenes in the laboratory walking bioassay were $1680 \mu \mathrm{g} / \mathrm{h}$ for each enantiomer of $\alpha$ pinene, $565 \mu \mathrm{g} / \mathrm{h}$ for 3 -carene, and $289 \mu \mathrm{g} / \mathrm{h}$ for terpinolene, and these rates were estimated to be equivalent to the release of the major monoterpenes from three freshly cut logs of Scotch pine $(30 \mathrm{~cm} \times 13 \mathrm{~cm}$ diameter $)[9,14,15]$. In contrast to walking beetles in the olfactometer, attraction by flying $P$. bidentatus to aggregation pheromone in the field was significantly reduced by these same monoterpenes at $0.1 \log$-equivalent $(60 \mu \mathrm{g} / \mathrm{h})$ or $1 \log$-equivalent $(600 \mu \mathrm{g} / \mathrm{h})$ dispensed from a piezoelectric sprayer (Figure 3) [9]. Thus, release rates of monoterpenes that failed to inhibit attraction to pheromone by walking beetles in the laboratory were equivalent [7] or higher [9] than rates that inhibited attraction of flying beetles in the field.

Natural selection should favor conifer-infesting bark beetles that find their host tree by keying on pheromones and/or host volatiles of which the monoterpenes are the most abundant. Some bark beetles such as T. piniperda and to a lesser extent $T$. minor are strongly attracted to monoterpene vapors emanating from resinous wounds incurred when the trees fall during winter and spring storms [14-16]. Monoterpenes are also weakly attractive to secondary bark beetles that follow the tree-killing beetles after the tree succumbs [17]. $(-)-\alpha$-Pinene weakly attracted Ips grandicollis (Eichhoff) and Dendroctonus valens LeConte but not $I$. avulsus (Eichhoff) or I. calligraphus (Germar) [23, 25]. Bark beetles that kill their host tree in a mass attack in the genera Ips and 
Dendroctonus are weakly or not attracted by monoterpenes alone ([23, 25, 44], Byers unpublished) although in some cases specific monoterpenes can enhance responses to aggregation pheromone, as occurs in $D$. brevicomis LeConte, $D$. pseudotsugae Hopkins, D. valens, D. frontalis Zimmermann, and I. grandicollis [20-25]. This also seems to be the case for tree-killing $P$. chalcographus that attack Norway spruce; both sexes were more attracted to aggregation pheromone components when either enantiomer of $\alpha$-pinene, (-)- $\beta$ pinene, or camphene was coreleased [18].

The aggressive bark beetles generally are not attracted to susceptible hosts by means of monoterpenes, but are believed to select hosts by a process of randomly landing on trees and determining their resistance level by boring through the outer bark $[45,46]$. If the tree produces enough resin, then the beetle must leave or be killed. If the beetle succeeds in feeding due to low host resistance, then aggregation pheromone is released that attracts many more individuals to overcome the tree. Thus, the vast majority of individuals in the tree-killing bark beetle species find their host tree by orienting to aggregation pheromone $[46,47]$. P. bidentatus appears to be much less aggressive, preferring to colonize only broken or weakened limbs of pine in which resin production as a defense is greatly reduced or nonexistent [14]. As the tree becomes colonized and begins to degrade, higher rates of verbenone and ethanol are released that reduce attraction of many of the bark beetle species to pheromone or host monoterpenes [11, 15, 17, 33, 48-50]. In $P$. bidentatus, however, ethanol reduced, while verbenone did not reduce, response to aggregation pheromone in tests with trap pair slow-rotation [7].

The open-arena olfactometer used here is a bioassay that has been tested on several bark beetle species, and individuals of both sexes commonly behave in a way that is consistent with trap captures in the field. For example, walking $I$. paraconfusus are increasingly attracted to higher doses of aggregation pheromone components in the laboratory [39, 51], but at the higher release rates the males are increasingly less attracted, just as in the field [51]. In D. brevicomis, walking females and males are increasingly attracted to their aggregation pheromone components in the olfactometer, and release of male-produced verbenone causes both sexes to avoid the aggregation pheromone source; the same behaviors that occur when flying beetles respond to baited traps in the field $[40,41]$. Both sexes of $D$. brevicomis produce transverbenol during feeding in ponderosa pine [52], and only females are inhibited by higher concentrations of (-)-transverbenol either when walking in the olfactometer or when entering holes in carton traps in the field [42]. Another study with the olfactometer has shown that walking T. piniperda are attracted to host monoterpenes as well as similarly attracted when flying to host logs or monoterpenes in sticky traps [14]. Walking $P$. chalcographus are increasingly attracted in the laboratory olfactometer to increasing release of their pheromone components, and subtraction of the monoterpene fraction from an odor collection of a male-infested log caused a moderate decrease in attraction [19]. This is in agreement with a field study showing monoterpenes increasing flight attraction and proportionally greater entry of walking $P$. chalcographus through small holes into traps releasing aggregation pheromone components [18].

Thus, in all cases except the present study, bark beetle behavior in the open-arena olfactometer has been in general agreement with the behavior observed in the field with traps baited with semiochemicals. If there were different bioassay operators, this might explain the discrepancy between flight and walking behaviors in P. bidentatus; however, the same person (Byers) performed all laboratory bioassays discussed above $[14,18,19,39-42,51,52]$. Rather, the differences appear to be explained by the ecology of $P$. bidentatus that appears less aggressive and colonizes unhealthy branches, in contrast to the pest bark beetles mentioned above that often kill trees. Six possible combinations of behavior could have evolved in $P$. bidentatus when responding to aggregation pheromone in regard to whether to respond, ignore, or avoid monoterpene odors while flying or walking. The best adaptation for a less aggressive bark beetle such as $P$. bidentatus that prefers to colonize weakened and diseased branches or smaller unhealthy trees would be to avoid monoterpenes when flying (so as to not land in resin and more efficiently select suitable hosts from among resistant hosts and nonhosts) but not when walking (so as to enter holes made by mates or excavate entrance holes where concentrations of monoterpenes are higher). Other more aggressive bark beetles may not avoid monoterpenes in combination with aggregation pheromone while flying because these species are suited to tolerate resin when overcoming the tree's resistance [11].

The monoterpenes were not tested alone in the rotating traps in the field or in the laboratory bioassay so it is not known if they could be attractive to P. bidentatus at some concentration. However, Byers [17] tested monoterpenes (enantiomers of $\alpha$-pinene, 3 -carene, and terpinolene, each at $104 \mu \mathrm{g} / \mathrm{h}$ to $583 \mu \mathrm{g} / \mathrm{h}$ ) or a combination of ethanol and monoterpenes in the field during the spring in the same location as the present study; neither P. bidentatus nor any other Pityogenes species were caught even though five other bark beetle species were attracted.

It is proposed that pheromone-producing bark beetles that are not attracted to monoterpenes or other hostassociated odors may initially land on trees at random in response to the visual silhouette of the trunk $[45,51]$. Once a beetle bores into a suitable tree and is able to produce aggregation pheromone, a mass colonization ensues. The presence of aggregation pheromone indicates an ongoing colonization by $P$. bidentatus and thus is a cue to the likely presence of a weakened host and a valuable resource to be exploited. Conifers usually produce resinous wounds in response to mechanical damage from storms or other causes, and the exposed resin poses a hazard to bark beetles orienting to and attempting to colonize these trees. The visual acuity of bark beetles, with about 200 facets per eye [11], probably does not allow beetles to differentiate resin globules and resinous patches on a tree trunk or branch before they land. T. piniperda, I. typographus L., and P. chalcographus beetles walking on the bark of wounded conifers in Sweden that happened to contact resin globules were seen to back away and turn to find a path free of resin (personal observations). 
It is probable that $P$. bidentatus similarly avoid resin while walking. It is also expected that fitness of P. bidentatus would be enhanced when responding to aggregation pheromone if they could avoid both potentially fatal landings in resinous patches and bark unsuitable for colonization due to a tree's vigorous resin defenses. In addition, flying beetles would save time and energy by avoiding monoterpenes of fresh host trees as well as nonhost trees in the vicinity of a suitable host. Healthy trees capable of exuding resin from wounds probably would be unsuitable hosts for P. bidentatus, since they typically attack diseased and dying branches possessing compromised resin defenses. After landing, the beetles may seek out the source of aggregation pheromone while relying on their ability to back away from any sticky resin they encounter while walking.

It is likely that no species of conifer-infesting bark beetle would be repelled by monoterpenes while walking on the bark surface and orienting to pheromone, since they must encounter high concentrations of monoterpenes either when they enter the gallery of a mate or initiate a new gallery. To my knowledge, no tests of bark beetles walking in laboratory olfactometers and orienting to aggregation pheromone have shown monoterpenes to be repellent. P. bidentatus is not the only bark beetle that is inhibited by host volatiles in flight since $I$. avulsus response to aggregation components was inhibited by high releases of loblolly pine turpentine (undefined mixture of monoterpenes at 150,000 $\mu \mathrm{g} / \mathrm{h}$ ) [25] and I. pini (Say) flight response to its aggregation components was inhibited by racemic $\alpha$-pinene at high rates $(23,000 \mu \mathrm{g} / \mathrm{h})$ [24]. It is not known how I. pini or I. avulsus respond to monoterpenes and aggregation pheromone when walking.

Further work with $P$. bidentatus is needed to understand the conditions and benefits of ignoring monoterpene odors while walking but avoiding these odors when flying. It appears remarkable that this tiny insect is able to exhibit two types of behavior in regard to aggregation pheromone and monoterpenes. The first behavior of avoiding monoterpenes when flying seems adaptive in that a beetle averts plunging into sticky resin that could entrap them and saves time/energy during searches for suitable hosts. The second behavior of ignoring monoterpene vapors when walking also seems adaptive to find colonization areas and entrance holes of mates on the bark, and escaping any encountered resin by backing away. The possibility of dichotomy in behaviors when flying and walking needs to be investigated in other species of bark beetles to understand the adaptive benefits.

\section{Acknowledgments}

This study was supported by grants from the Swedish Agricultural and Forestry Research Council (SJFR) to the Swedish University of Agricultural Sciences, Alnarp, Sweden.

\section{References}

[1] B. Lekander, B. Bejer Peterson, F. Kangas, and A. Bakke, "The distribution of bark beetles in the Nordic countries," Acta Entomologia Fennica, vol. 32, pp. 1-36, 1977.
[2] I. Amezaga and M. A. Rodríguez, "Resource partitioning of four sympatric bark beetles depending on swarming dates and tree species," Forest Ecology and Management, vol. 109, no. 1-3, pp. 127-135, 1998.

[3] P. Martikainen, J. Siitonen, L. Kaila, and P. Punttila, "Intensity of forest management and bark beetles in non-epidemic conditions: a comparison between Finnish and Russian Karelia," Journal of Applied Entomology, vol. 120, no. 5, pp. 257-264, 1996.

[4] K. Tunset, A. C. Nilssen, and J. Andersen, "Primary attraction in host recognition of coniferous bark beetles and bark weevils (Coleoptera: scolytidae and curculionidae)," Journal of Applied Entomology, vol. 115, no. 2, pp. 155-169, 1993.

[5] V. E. J. Baader, "Pityogenes spp. (Col., Scolytidae): utersuchungen über verhaltenssteuernde Duftstoffe und deren Anwendung im Waldschutz," Journal of Applied Entomology, vol. 107, no. 1, pp. 1-31, 1989.

[6] W. Francke, J. Bartels, H. Meyer et al., "Semiochemicals from bark beetles: new results, remarks, and reflections," Journal of Chemical Ecology, vol. 21, no. 7, pp. 1043-1063, 1995.

[7] J. A. Byers, Q. H. Zhang, and G. Birgersson, "Strategies of a bark beetle, Pityogenes bidentatus, in an olfactory landscape," Naturwissenschaften, vol. 87, no. 11, pp. 503-507, 2000.

[8] J. A. Byers, Q. H. Zhang, and G. Birgersson, "Avoidance of nonhost plants by a bark beetle, Pityogenes bidentatus, in a forest of odors," Naturwissenschaften, vol. 91, no. 5, pp. 215219, 2004.

[9] A. M. El-Sayed and J. A. Byers, "Inhibitory effect of monoterpenes on response of Pityogenes bidentatus to aggregation pheromone released by piezoelectric sprayer for precision release of semiochemicals," Journal of Chemical Ecology, vol. 26, no. 8, pp. 1795-1809, 2000.

[10] J. H. Tumlinson, D. D. Hardee, R. C. Gueldner, A. C. Thompson, P. A. Hedin, and J. P. Minyard, "Sex pheromones produced by male boll weevil: isolation, identification, and synthesis," Science, vol. 166, no. 3908, pp. 1010-1012, 1969.

[11] J. A. Byers, "Host tree chemistry affecting colonization in bark beetles," in Chemical Ecology of Insects 2, R. T. Cardé and W. J. Bell, Eds., pp. 154-213, Chapman and Hall, New York, NY, USA, 1995.

[12] J. A. Byers and G. Birgersson, "Pheromone production in a bark beetle independent of myrcene precursor in host pine species," Naturwissenschaften, vol. 77, no. 8, pp. 385-387, 1990.

[13] V. Thoss and J. A. Byers, "Monoterpene chemodiversity of ponderosa pine in relation to herbivory and bark beetle colonization," Chemoecology, vol. 16, no. 1, pp. 51-58, 2006.

[14] J. A. Byers, B. S. Lanne, J. Löfqvist, F. Schlyter, and G. Bergström, "Olfactory recognition of host-tree susceptibility by pine shoot beetles," Naturwissenschaften, vol. 72, no. 6, pp. 324-326, 1985.

[15] J. A. Byers, B. S. Lanne, and J. Löfqvist, "Host tree unsuitability recognized by pine shoot beetles in flight," Experientia, vol. 45, no. 5, pp. 489-492, 1989.

[16] B. S. Lanne, F. Schlyter, J. A. Byers et al., "Differences in attraction to semiochemicals present in sympatric pine shoot beetles, Tomicus minor and T. piniperda," Journal of Chemical Ecology, vol. 13, no. 5, pp. 1045-1067, 1987.

[17] J. A. Byers, "Attraction of bark beetles, Tomicus piniperda, Hylurgops palliatus, and Trypodendron domesticum and other insects to short-chain alcohols and monoterpenes," Journal of Chemical Ecology, vol. 18, no. 12, pp. 2385-2402, 1992. 
[18] J. A. Byers, G. Birgersson, J. Löfqvist, and G. Bergström, "Synergistic pheromones and monoterpenes enable aggregation and host recognition by a bark beetle, Pityogenes chalcographus," Naturwissenschaften, vol. 75, no. 3, pp. 153-155, 1988.

[19] J. A. Byers, G. Birgersson, J. Löfqvist, M. Appelgren, and G. Bergström, "Isolation of pheromone synergists of bark beetle, Pityogenes chalcographus, from complex insect-plant odors by fractionation and subtractive-combination bioassay," Journal of Chemical Ecology, vol. 16, no. 3, pp. 861-876, 1990.

[20] W. D. Bedard, P. E. Tilden, D. L. Wood, R. M. Silverstein, R. G. Brownlee, and J. O. Rodin, "Western pine beetle: field response to its sex pheromone and a synergistic host terpene, myrcene," Science, vol. 164, no. 3885, pp. 1284-1285, 1969.

[21] R. A. Werner, "Response of the beetle, Ips grandicollis, to combinations of host and insect produced attractants," Journal of Insect Physiology, vol. 18, no. 7, pp. 1403-1412, 1972.

[22] J. A. Rudinsky, M. M. Furniss, L. N. Kline, and R. F. Schmitz, "Attraction and repression of Dendroctonus pseudotsugae (Coleoptera: Scolytidae) by three synthetic pheromones in traps in Oregon and Idaho," Canadian Entomologist, vol. 104, no. 6, pp. 815-822, 1972.

[23] N. Erbilgin and K. F. Raffa, "Opposing effects of host monoterpenes on responses by two sympatric species of bark beetles to their aggregation pheromones," Journal of Chemical Ecology, vol. 26, no. 11, pp. 2527-2548, 2000.

[24] N. Erbilgin, J. S. Powell, and K. F. Raffa, "Effect of varying monoterpene concentrations on the response of Ips pini (Coleoptera: Scolytidae) to its aggregation pheromone: implications for pest management and ecology of bark beetles," Agricultural and Forest Entomology, vol. 5, no. 4, pp. 269-274, 2003.

[25] R. F. Billings, "Southern pine bark beetles and associated insects: effects of rapidly-released host volatiles on response to aggregation pheromones," Journal of Applied Entomology, vol. 99, no. 5, pp. 483-491, 1985.

[26] J. C. Dickens, R. F. Billings, and T. L. Payne, "Green leaf volatiles interrupt aggregation pheromone response in bark beetles infesting southern pines," Experientia, vol. 48, no. 5, pp. 523-524, 1992.

[27] L. M. Schroeder, "Olfactory recognition of nonhosts aspen and birch by conifer bark beetles Tomicus piniperda and Hylurgops palliatus," Journal of Chemical Ecology, vol. 18, no. 9, pp. 15831593, 1992.

[28] I. M. Wilson, J. H. Borden, R. Gries, and G. Gries, "Green leaf volatiles as antiaggregants for the mountain pine beetle, Dendroctonus ponderosae Hopkins (Coleoptera: Scolytidae)," Journal of Chemical Ecology, vol. 22, no. 10, pp. 1861-1875, 1996.

[29] A. Guerrero, J. Feixas, J. Pajares, L. J. Wadhams, J. A. Pickett, and C. M. Woodcock, "Semiochemically induced inhibition of behaviour of Tomicus destruens (Woll.) (Coleoptera: Scolytidae)," Naturwissenschaften, vol. 84, no. 4, pp. 155-157, 1997.

[30] J. H. Borden, L. J. Chong, A. Savoie, and I. M. Wilson, "Responses to green leaf volatiles in two biogeoclimatic zones by striped ambrosia beetle, Trypodendron lineatum," Journal of Chemical Ecology, vol. 23, no. 11, pp. 2479-2491, 1997.

[31] J. H. Borden, I. M. Wilson, R. Gries, L. J. Chong, H. D. Pierce, and G. Gries, "Volatiles from the bark of trembling aspen, Populus tremuloides Michx. (Salicaceae) disrupt secondary attraction by the mountain pine beetle, Dendroctonus pondevosae Hopkins (Coleoptera: Scolytidae)," Chemoecology, vol. 8, no. 2, pp. 69-75, 1998.

[32] E. K. Deglow and J. H. Borden, "Green leaf volatiles disrupt and enhance response to aggregation pheromones by the ambrosia beetle, Gnathotrichus sulcatus (Coleoptera: Scolytidae)," Canadian Journal of Forest Research, vol. 28, no. 11, pp. 1697-1705, 1998.

[33] J. A. Byers, Q. H. Zhang, F. Schlyter, and G. Birgersson, "Volatiles from nonhost birch trees inhibit pheromone response in spruce bark beetles," Naturwissenschaften, vol. 85, no. 11, pp. 557-561, 1998.

[34] Q. H. E. Zhang, G. Birgersson, J. Zhu, C. Löfstedt, J. Löfqvist, and F. Schlyter, "Leaf volatiles from nonhost deciduous trees: variation by tree species, season and temperature, and electrophysiological activity in Ips typographus," Journal of Chemical Ecology, vol. 25, no. 8, pp. 1923-1943, 1999.

[35] Q. H. Zhang, F. Schlyter, and P. Anderson, "Green leaf volatiles interrupt pheromone response of spruce bark beetle, Ips typographus," Journal of Chemical Ecology, vol. 25, no. 12, pp. 2847-2861, 1999.

[36] D. P. W. Huber, R. Gries, J. H. Borden, and H. D. Pierce Jr., "Two pheromones of coniferophagous bark beetles found in the bark of nonhost angiosperms," Journal of Chemical Ecology, vol. 25, no. 4, pp. 805-816, 1999.

[37] T. M. Poland and R. A. Haack, "Pine shoot beetle, Tomicus piniperda (Col., Scolytidae), responses to common green leaf volatiles," Journal of Applied Entomology, vol. 124, no. 2, pp. 63-69, 2000.

[38] J. A. Byers, F. Schlyter, G. Birgersson, and W. Francke, "E-myrcenol in Ips duplicatus: an aggregation pheromone component new for bark beetles," Experientia, vol. 46, no. 1112, pp. 1209-1211, 1990.

[39] J. A. Byers, D. L. Wood, L. E. Browne, R. H. Fish, B. Piatek, and L. B. Hendry, "Relationship between a host plant compound, myrcene and pheromone production in the bark beetle, IPS paraconfusus," Journal of Insect Physiology, vol. 25, no. 6, pp. 477-482, 1979.

[40] J. A. Byers and D. L. Wood, "Interspecific inhibition of the response of the bark beetles, Dendroctonus brevicomis and Ips paraconfusus, to their pheromones in the field," Journal of Chemical Ecology, vol. 6, no. 1, pp. 149-164, 1980.

[41] J. A. Byers and D. L. Wood, "Interspecific effects of pheromones on the attraction of the bark beetles, Dendroctonus brevicomis and Ips paraconfusus in the laboratory," Journal of Chemical Ecology, vol. 7, no. 1, pp. 9-18, 1981.

[42] J. A. Byers, "Bark beetle conversion of a plant compound to a sex-specific inhibitor of pheromone attraction," Science, vol. 220, no. 4597, pp. 624-626, 1983.

[43] L. E. Browne, M. C. Birch, and D. L. Wood, "Novel trapping and delivery systems for airborne insect pheromones," Journal of Insect Physiology, vol. 20, no. 1, pp. 183-193, 1974.

[44] F. Schlyter, G. Birgersson, J. A. Byers, J. Löfqvist, and G. Bergström, "Field response of spruce bark beetle, Ips typographus, to aggregation pheromone candidates," Journal of Chemical Ecology, vol. 13, no. 4, pp. 701-716, 1987.

[45] H. A. Moeck, D. L. Wood, and K. Q. Lindahl, "Host selection behavior of bark beetles (Coleoptera: Scolytidae) attacking Pinus ponderosa, with special emphasis on the western pine beetle, Dendroctonus brevicomis," Journal of Chemical Ecology, vol. 7, no. 1, pp. 49-83, 1981.

[46] J. A. Byers, "Effects of attraction radius and flight paths on catch of scolytid beetles dispersing outward through rings of pheromone traps," Journal of Chemical Ecology, vol. 25, no. 5, pp. 985-1005, 1999.

[47] J. A. Byers, "An encounter rate model of bark beetle populations searching at random for susceptible host trees," Ecological Modelling, vol. 91, no. 1-3, pp. 57-66, 1996. 
[48] A. Bakke, "Inhibition of the response in Ips typographus to the aggregation pheromone: field evaluation of verbenone and ipsenol," Zeitschrift für Angewandte Entomologie, vol. 92, no. 2, pp. 172-177, 1981.

[49] D. Klimetzek, J. Kohler, J. P. Vite, and U. Kohnle, "Dosage response to ethanol mediates host selection by "secondary" bark beetles," Naturwissenschaften, vol. 73, no. 5, pp. 270-272, 1986.

[50] J. A. Byers, "Avoidance of competition by spruce bark beetles, Ips typographus and Pityogenes chalcographus," Experientia, vol. 49, no. 3, pp. 272-275, 1993.

[51] J. A. Byers, "Sex-specific responses to aggregation pheromone Regulation of colonization density in the bark beetle Ips paraconfusus," Journal of Chemical Ecology, vol. 9, no. 1, pp. 129-142, 1983.

[52] J. A. Byers, D. L. Wood, J. Craig, and L. B. Hendry, "Attractive and inhibitory pheromones produced in the bark beetle, Dendroctonus brevicomis, during host colonization: regulation of inter- and intraspecific competition," Journal of Chemical Ecology, vol. 10, no. 6, pp. 861-877, 1984. 

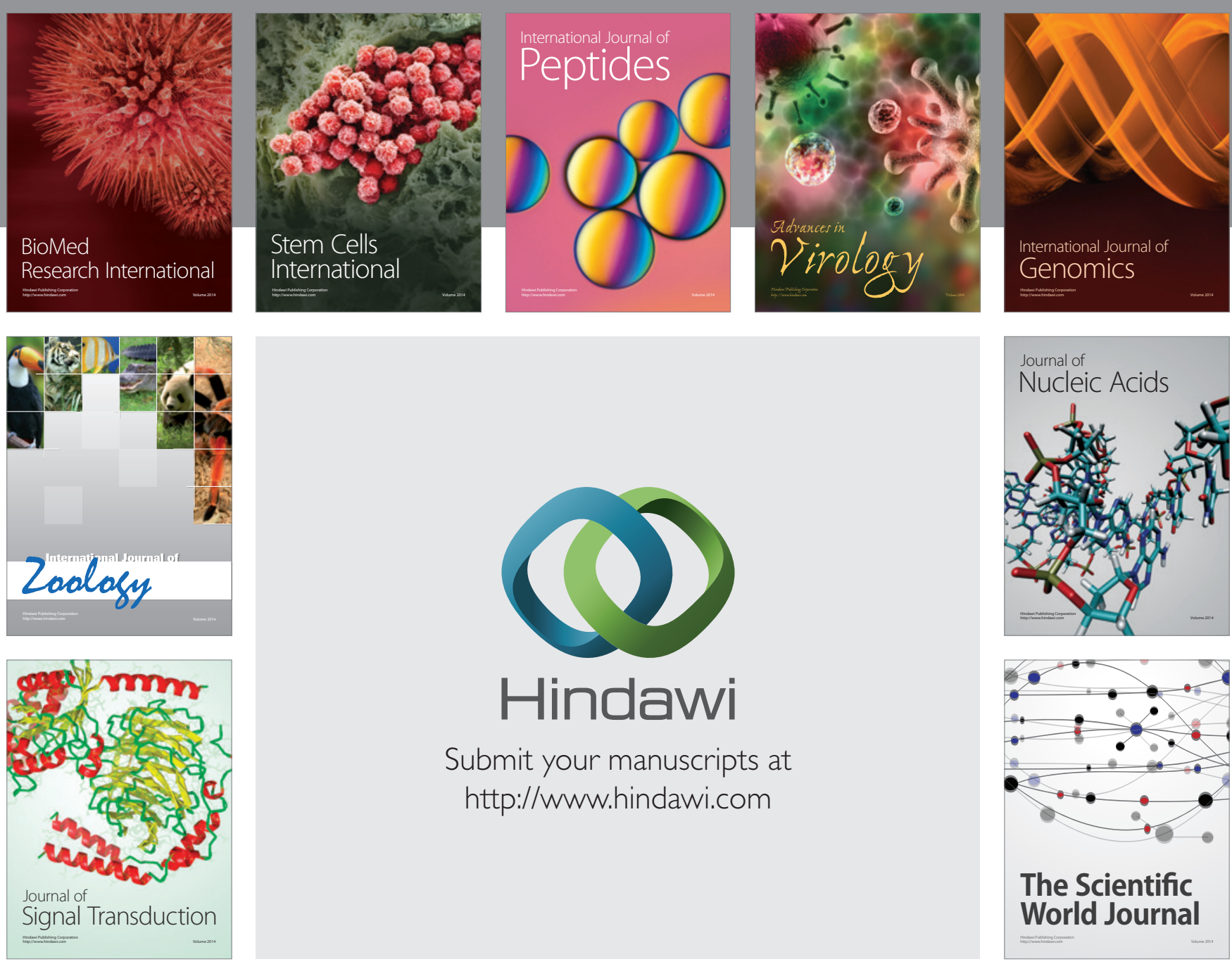

Submit your manuscripts at

http://www.hindawi.com
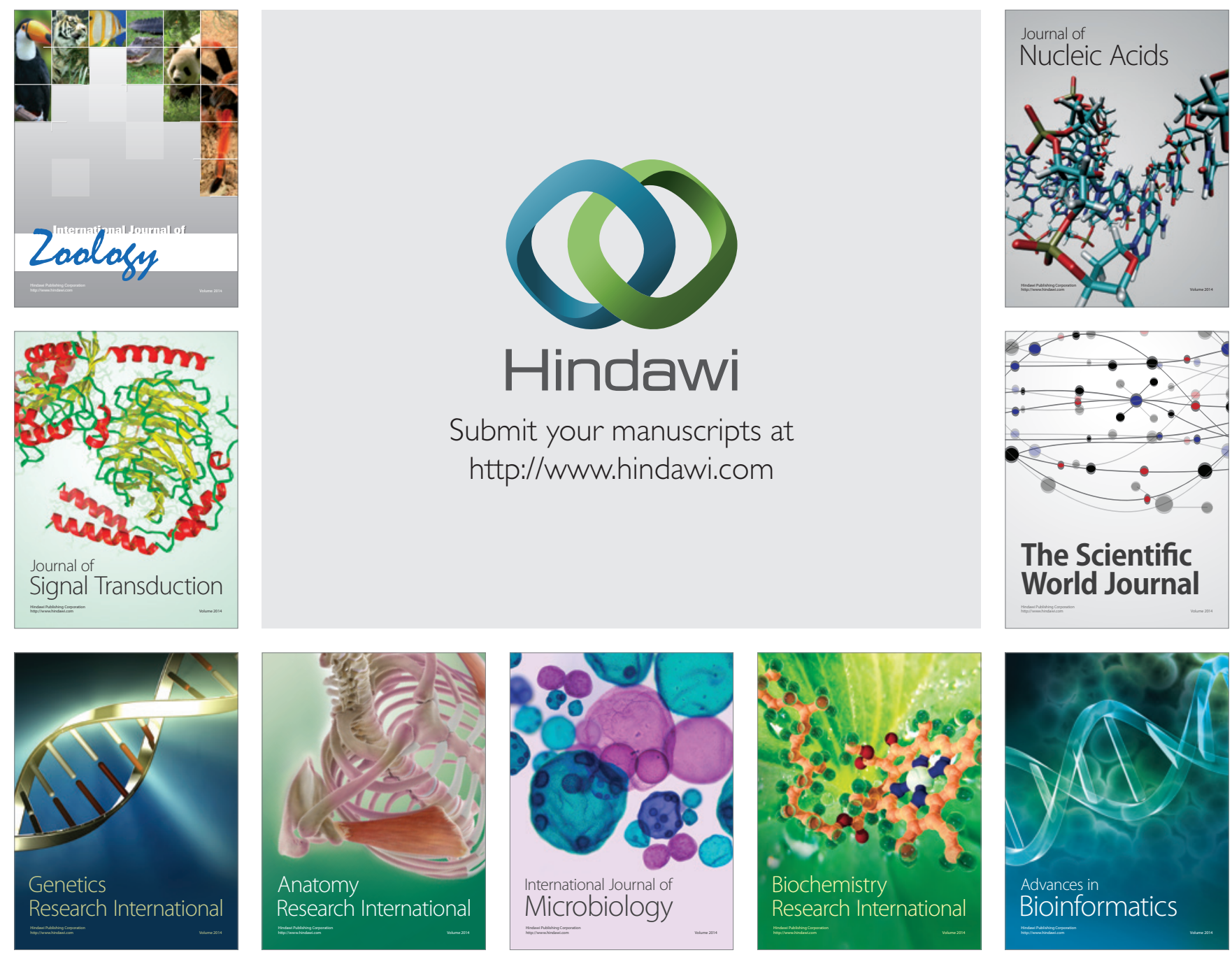

The Scientific World Journal
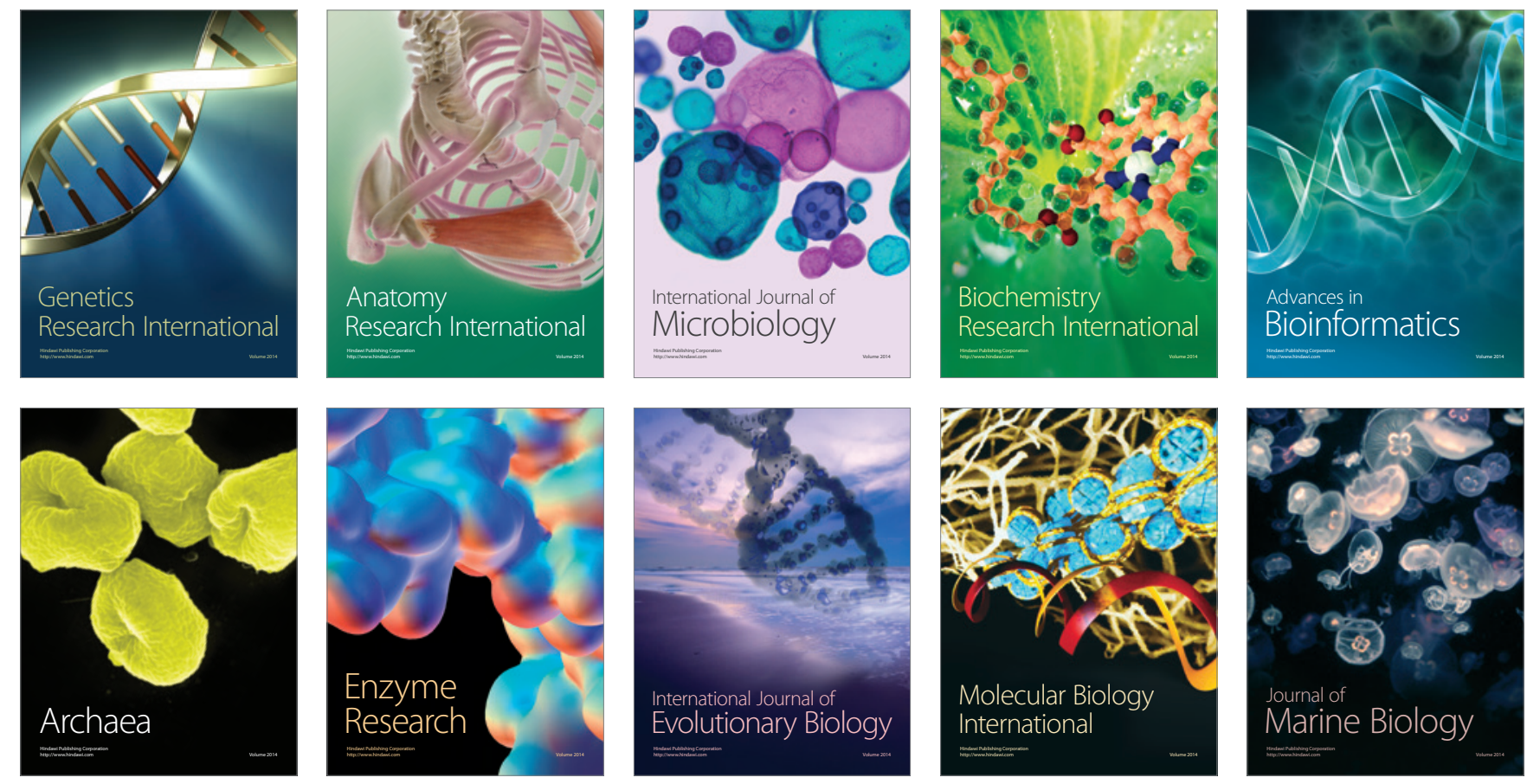